\title{
Banking Deviant Behavior: Literature Analysis on Government Ownership Bank in Indonesia
}

\author{
Budi Widadi $^{1}$, Fania Mutiara Savitri ${ }^{2}$ \\ \{im.vanee@gmail.com ${ }^{2}$ \} \\ Universitas Diponegoro, Indonesia ${ }^{1}$ \\ Universitas Islam Negeri Walisongo, Indonesia ${ }^{2}$
}

\begin{abstract}
Wardani and Yousef [1] found that around 33 to $75 \%$ of employees have done some deviation at their work. The previous gap phenomenon in banking organizations is that they are supposed to work according to company values that have been implanted when bank employees follow a continuous recruitment and training process. This study aims to examine deviant behavior literature that occurs in the government-owned banking industry in Indonesia. Further, this study has proposed to get new constructs regarding deviant behavior background and describe them well. This study uses the literature analysis method at PT. XYZ Bank (Persero). Literature analysis uses a logic flow that is built from a review of the theory and previous research synthesis, and the material is combined with the tendency of the real phenomenon captured by the researcher. The approach used is social psychology and behavioral psychology. This study indicates that the existence of synthesis and derivation between social psychology and behavioral psychology is supported by social norms that manifest in deviant opportunities, low emotional control, and interactional injustice as the beginning of deviant behavior. This research's implications can be developed in-depth analysis with the mix method for the banker who is at risk of making irregularities.
\end{abstract}

Keywords: Deviant Behavior, Low Emotional Control, Interactional Injustice

\section{Introduction}

Deviant behavior is also known as out of order behavior [2][3]. It is also defined as employee behavior deliberately done by disobeying organizational norms and/or formal society rules and could have negative consequences. According to Kreitner and Kinicki [4], deviant behavior is known as counterproductive work behavior, which means a type of harmful behavior for employees and the company. Robbins and Judge [3] states that who have spent a lot of time in an organization will realize that some employees who behave violate the norms; they will threaten the organization and its members. These actions are called workplace deviant behavior $[3][5][6]$.

Wardani and Yousef [1] found that around 33 to $75 \%$ of employees have experienced deviation to the organization where they work. There are several researchers in various countries such as in Iran [7], Nigeria [8][9], Malaysia [10], Sri Lanka [11] and also in Pakistan [12]. Raza et al. [13] who have studied this specific behavior. Deviant behavior in Pakistan is workplace deviant in the banking sector done by Bank internal parties [12]. Raza et al. [13], showing a less good portrait of banking services as a trusted party in managing public finances. 
One of the deviant behaviors that are often happened in the banking sector is a fraud [14]. The bank needs to manage its employee's behavior to be more optimal and effective to realize competitive advantage goals [15]. Banks that can increase access to finance will have a positive impact on growing corporate profits.

Effective banking performance is strongly supported by employees' positive behavior [16]. Banking managers are often faced with deviant behavior. The number of deviant behaviors in the banking sector has created a specific concern for investors and customer anxiety due to deviant behavior done by an irresponsible individual. According to Albrecht et al. [14], Arens et al. [17], and Zack [18], Fraud is generally used to describe actions such as deceiving, bribery, forgery, coercion, corruption, theft, conspiracy, embezzlement, abuse, fact concealment and collusion [16].

The deviant behavior of banking sector studies in Indonesia is still limited. Based on Anung Herlianto's findings, Director of Bank Supervision II of the OJK, about $93 \%$ of bank burglary cases were revealed, there is insider's involvement. This statement is strengthened by the AntiFraud Foundation survey on financial-sector employee's performance, which showed that $70 \%$ of people who work in the financial sector are dishonest. $50 \%$ of them did not mind behaving fraud if there are a need, opportunity, and rationalization (www.mediaindonesia.com, 2019).

The banking sector has implied fraud management to reduce the types of crimes (minor and major). Sometimes, this management has been conducted by collaborating with customers. Moreover, an exclusive interview with President Director of PT Bank XYZ (Persero) Tbk., Kartika Wirjoatmodjo, banking crimes has ever been due to several cases. Including fraud in credit disbursement, bank guarantees, database theft, falsification of demand deposits forgery, fund embezzlement, banking asset theft, money tucked on the teller, and much more. The findings of Bank XYZ's internal parties related to fraud presented in the table below:

Table 1. Internal Fraud PT. Bank XYZ Tbk. (Persero) 2014-2018

\begin{tabular}{|l|c|c|c|c|c|c|c|c|c|c|}
\hline \multirow{3}{*}{ Internal Fraud } & \multicolumn{4}{|c|}{ The number of cases did by } \\
\cline { 2 - 11 } & \multicolumn{4}{|c|}{ Settle employee } & \multicolumn{5}{c|}{$\begin{array}{c}\text { Employee on agreement } \\
\text { contract }\end{array}$} \\
\cline { 2 - 11 } & $\mathbf{2 0 1 4}$ & $\mathbf{2 0 1 5}$ & $\mathbf{2 0 1 6}$ & $\mathbf{2 0 1 7}$ & $\mathbf{2 0 1 8}$ & $\mathbf{2 0 1 4}$ & $\mathbf{2 0 1 5}$ & $\mathbf{2 0 1 6}$ & $\mathbf{2 0 1 7}$ & $\mathbf{2 0 1 8}$ \\
\hline Total Fraud & 73 & 71 & 74 & 78 & 85 & 41 & 43 & 45 & 46 & 48 \\
\hline Solved & 73 & 71 & 74 & 78 & 85 & 41 & 43 & 45 & 46 & 48 \\
\hline
\end{tabular}

Source: Internal Audit PT. Bank XYZ Tbk. (Persero).

Table 1 shows of fraud \& Non-Fraud cases had solved well, but company image loss is unresolved. There are material and immaterial losses caused by internal fraud. As long as there is an opportunity to benefit from personal gain, there is always an opportunity to do conspiracy, corruption, and much other fraud; it will be significant on tough economic growth conditions.

Regarding the existence of empirical phenomena regarding deviant behavior globally occurs in organizations, the problem in this study is: Is there involvement from the social psychology or the psychology on employee's deviant behavior in organizations. Therefore, this study examines the literature on deviations, especially from social psychology and behavioral psychology, that occurs in Indonesia's government-owned banking. 


\section{Literature Review}

Social exchange theory belongs to the social behavior paradigm, which can be explained from two theoretical perspectives. First, behavioral sociology theory. This theory was built to apply the principles of behavioral psychology to sociology. The basic concept of Behavioral Sociology is reinforcement, which means reward. There is no inherent on the object, which can raise compensation. Behavior repetition cannot be defined regardless of the effect on the behavior itself. Second, the exchange theory explained by George Homans was constructed as a reaction against the paradigm of social facts; it was particularly attacking Durkheim's ideas. The social exchange point of view argues that people calculate the overall value of a relationship by subtracting the sacrifice from the compensation received [19].

There are many types of deviant behavior. This behavior is very detrimental to the organization and the customer. According to Silva and Ranasinghe [11], Some action is linked to direct organization costs. Deviant behavior is shown by counterproductive behavior, which is generally caused by excessive workload, relationships with other people, family life, managerial roles, high responsibility, and busyness [20]. Indicators that can be used in measuring individual deviant behavior which has been modified based on banking characteristic [1] as follows:

1. Fraud-deviant behavior is the experience of identifying colleagues committing corruption, fraud, theft, embezzlement, and forgery.

2. Non-Fraud-deviant behavior is the experience of identifying colleagues who disclose Bank secrets for personal gain, be a negative insider, behave immoral acts inside and outside the company, doing the harassment, use drugs and engage in prohibited community activities.

\section{Methodology}

This study examines and analyzes the literature systematically and appropriately for research problem solving [21]. The following some steps as a guide for researchers/writers to produce a good literacy: 1) Search the appropriate literature and efficiently scan the literature from information sources; 2) Value literature through several criteria; 3) Examine and analyze literature content systematically; 4) Synthesis of literature content.

\section{Results and Discussion}

Deviant behavior is related to behavioral-organization. First, organizational behavior was based on social psychology and behavioral psychology. Several factors cause employees to act irregularities. Opportunities that can be identified by individuals with specific characteristics, attitudes, emotions, and identities will make it possible to manifest these deviations. Based on cases that show internal parties who commit fraud, the unit analysis of this research is senior employees who identified the deviant behavior in PT. XYZ Bank (Persero). By observing through much literature, corporate fraud data, and brief interview's manuscript with the executive of PT Bank XYZ (Persero) Tbk., there is a new concept that underlies employee's deviant behavior.

One of the Big Five Personality components is neuroticism [22][23][24][2]. Neuroticism is a personality dimension that assesses a person's ability to withstand pressure or stress [25]. 
Positive neuroticism characteristics can be interpreted as emotional stability; individuals with emotional stability tend to be calm when facing problems, confident, and have tough thinking. At the same time, the personality characteristics of neuroticism with negative traits are often nervous, depressed, insecure, and easy to change their mind [26]. The personality dimension of neuroticism in a negative side is often referred to as Emotional stability. Some call Natural React as a positive side dimension [27].

Emotional stability is the ability to control feelings and self-emotions and personal emotion by sorting everything out and using it to guide thoughts and actions [28]. According to van der Linden et al. [27], there are several aspects used to measure emotional stability: including emotional adequacy (responding to situations calmly and regulating emotions and feelings according to the demands of the situation); Emotional maturity (able to adjust the pressure, not easily feel worried and not easily get angry) and Emotion Control (face situations with a rational attitude; be able to respond appropriately and not overly judge situations).

Emotional control is a necessary construct to measure emotional stability. Some researchers express this, such as Arora and Rangnekar [29], which states that emotional stability can control emotions and be rational simultaneously with the right conditions. Goleman [30] and Gross [31] also say that emotional stability is the ability to control emotions, control satisfaction, and regulate the mental condition. Regarding the issue raised in the research, when emotional control has collided with social norms, it is possible to have differences in organizational members' acceptance. The finding of deviant behavior is related to noncompliance with norms; this norm will affect a person's emotional control level. Low compliance with organizational norms creates pressure on organizational demands that affect an individual's psychology, that have a domino effect reducing an individual's emotional condition. Low emotional control is appointed as a construct in research that will be further analyzed when interacting with stress, which triggers deviant behavior in the organization.

In another perspective, deviant behavior can be caused by interactional injustice. Interactional justice is defined by the sociologist Schermerhorn as the extent to which people affected by decisions are treated with dignity and respect. Otherwise, interactional injustice means people perceive that they are not treated with dignity and respect. This theory focuses on people's interpersonal treatment when the procedure is applied [32]. Maintaining effort of organizational excellence and success requires the ability to manage and retain employees well; a supervisor must provide information and politely behave when dealing with subordinates [32].

According to Schermerhorn et al. [33], the Interactional justice theory assumes that justice occurs when the treatment is implemented, or wages allocation is considered fair. Interactional justice includes truthfulness, respect, decency, and justification. This element is vital to captures the essence of interpersonal treatment during the implementation of the procedure. Interactional justice consists of two different types, interpersonal justice and informational justice [34]. Interpersonal justice reflects how far people are treated politely, glorified, and respected. Then, informational justice emphasizes the accuracy and quality of the explanation that individuals received. Fair treatment from direct superiors showed by distributing wage levels will affect employee attitudes. The interactional justice theory explains that employees who perceive fairness in superior's treatment supposed to allocate wage levels; this will increase work commitment and job performance [2].

An organization consists of a group of people who give each other treatment related to their organization's role. This treatment is based on the norms that apply to the organization. Acceptance of treatment among members of the organization depends on the norms that apply in the organization. Deviant behavior is the impact of non-compliance with social norms that apply in the workplace. This non-compliance is indicated by the perception of individuals who 
are treated differently in the organization. These individuals feel that they do not receive justice, both interpersonal and informational. Based on these assumptions, the interaction of interactional injustice with work pressure is able to encourage individual deviant behavior.

Organizations consist of a group of people who treat each other regarding their role in the organization. This treatment is based on the norms that apply to the organization. Treatment acceptance among organization members depends on the norms that apply in the organization. Deviant behavior is the impact of disobedience with social norms in the workplace. Disobedience is indicated by the individual's perception of who is treated differently in the organization. These individuals feel that they do not receive justice treatment, both interpersonal and informally. Based on these assumptions, the interaction of interactional injustice is able to encourage individual deviant behavior.

Regarding the perspective above, low self-control and interactional injustice will be novelties explaining deviant behavior through historical theory and concept. Organizational executives added the explanation that irregularities arise when individuals recognize an opportunity. Some other individuals do not use the opportunity because deviance is an option, especially for people whose interests are supported by low emotional control. Employee concern for the company can prevent deviants. This concern is owned by employees who have an excellent acceptance of their organization and accept employee and organization's roles that provide mutual benefits.

\section{Conclusion}

Deviant behavior study involves factors from social psychology and behavioral psychology disciplines in organizations. This study's results indicate that there are a synthesis and derivation between social psychology and behavioral psychology supported by social norms that manifested in opportunities to behave some types of fraud, low emotional control, and interactional injustice has become the starting point for deviant behavior.

Other empirical findings reveal the fact that the level of fraud in state-owned banks is difficult to eliminate but can still be suppressed. However, state-owned banks have a professional management system with values and cultures that uphold integrity. The existence of good corporate governance will return some lost losses. Besides, employee control management will increase a sense of engagement to the organization so that employees who previously had an interest in misbehaving can undo their intention.

The research can be developed better through in-depth analysis with the mix method for banking employees who risk act deviations. Mix method means that the investigation is carried out using qualitative and quantitative approaches to obtain objective results supported by related respondents' subjectivity. Low-emotional control and interactional injustice can be used as mediation or driving determinants of deviant behavior in government-owned banks.

\section{References}

[1] D. Wardani and Y. Yousef, "Pengaruh Gaji, Stres Kerja, dan Keadilan Interaksional terhadap Perilaku Penyimpangan Pegawai (Employee Deviance) Studi Kasus terhadap Divisi Marketing PT. XYZ,” J. Ekon. Manaj. dan Perbank. (Journal Econ. Manag. Banking), vol. 2, no. 1, pp. 3142, 2018.

[2] J. Greenberg, Behavior in Organizations: Global Edition. Pearson Higher Ed, 2014. 
[3] S. P. Robbins and T. A. Judge, "Organizational Behavior (17th Edition)." London: Pearson Education, 2016.

[4] S. L. McShane, M. A. Y. Von Glinow, and M. A. Von Glinow, Organizational behavior. McGraw-Hill Irwin New York, NY, 2005.

[5] F. Luthans, "Organizational behavior: An evidence-based approach.” McGraw-Hill Irwin, 2011.

[6] S. Fox and P. E. Spector, Counterproductive work behavior: Investigations of actors and targets, vol. 151. American Psychological Association Washington, DC, 2005.

[7] M. Golparvar, M. Taleb, F. Abdoli, and H. Abedini, "Stress coping styles moderating the relationship between job stress and deviant behaviors: Some gender discriminations," Am. J. Econ. Financ. Manag., vol. 1, no. 5, pp. 377-387, 2015.

[8] S. O. Salami, "Job stress and counterproductive work behaviour: Negative affectivity as a moderator,” Soc. Sci., vol. 5, no. 6, pp. 486-492, 2010.

[9] E. S. Ugwu and C. O. Okafor, "Organizational commitment, occupational stress, and core selfevaluation as predictors of workplace deviance," Am. J. Appl. Psychol., vol. 6, no. 4, pp. 64-70, 2017.

[10] Y. M. Adnan, H. Hamzah, M. M. Dali, M. N. Daud, and A. Alias, "An initiatives-based framework for assessing smart city," Plan. MALAYSIA, vol. 14, no. 5, 2016.

[11] H. M. S. Silva and R. Ranasinghe, "The impact of job stress on deviant workplace behaviour: A study of operational level employees of comfort apparel solutions company in Sri Lanka," Int. J. Hum. Resour. Stud., vol. 7, no. 1, pp. 74-85, 2017.

[12] H. Aftab and A. Javeed, "The impact of job stress on the counter-productive work behavior (CWB) A Case Study from the financial sector of Pakistan," Interdiscip. J. Contemp. Res. Bus., vol. 4, no. 7, pp. 590-604, 2012.

[13] S. Raza, M. S. Hussain, M. Azeem, and K. Aziz, "Workload, Work Stress, Role Conflict, and Workplace Deviant Behaviour in Banks: an Empirical Analysis," Eur. Online J. Nat. Soc. Sci., vol. 6, no. 4, p. pp-701, 2017.

[14] W. S. Albrecht, C. O. Albrecht, C. C. Albrecht, and M. F. Zimbelman, Fraud examination. Cengage Learning, 2015.

[15] S. Manacorda and C. Grasso, Fighting Fraud and Corruption at the World Bank: A Critical Analysis of the Sanctions System. Springer, 2018.

[16] J. T. Wells, Principles of fraud examination. Wiley Hoboken, NJ, 2008.

[17] A. A. Arens, R. J. Elder, and M. S. Beasley, "Auditing and Assurance Services: An Integrated Approach: Pearson Prentice Hall," 2012.

[18] G. M. Zack, Fair value accounting fraud: new global risks and detection techniques. John Wiley \& Sons, 2009.

[19] G. Ritzer and W. W. Murphy, Eds., The Wiley Blackwell Companion to Sociology, 2nd Edition. Wiley Blackwell Companions to Sociology, 2019.

[20] A.-C. Roxana, “Antecedents and mediators of employees' counterproductive work behavior and intentions to quit," Procedia-Social Behav. Sci., vol. 84, pp. 219-224, 2013.

[21] M. K. Nasution, "Penelaahan literatur. Teknik Penulisan Karya Ilmiah, 3. Sumatera utara. Researchgate." 2017.

[22] M. Armstrong and S. Taylor, Armstrong's handbook of human resource management practice. Kogan Page Publishers, 2020.

[23] M. K. Mount, M. R. Barrick, and A. M. Ryan, "Research themes for the future," Personal. Work Reconsidering role Personal. Organ., pp. 326-344, 2003.

[24] G. Dessler and B. Varrkey, Human Resource Management, 15e. Pearson Education India, 2005.

[25] M. Aamodt, Industrial/organizational psychology: An applied approach. Nelson Education, 2012.

[26] D. B. Smith and B. Schneider, "Where we've been and where we're going: Some conclusions regarding personality and organizations," Personal. Organ., pp. 387-404, 2004.

[27] D. van der Linden et al., "Overlap between the general factor of personality and trait emotional intelligence: a genetic correlation study," Behav. Genet., vol. 48, no. 2, pp. 147-154, 2018.

[28] J. Specht, Personality development across the lifespan. Academic Press, 2017. 
[29] R. Arora and S. Rangnekar, "Relationships between emotional stability, psychosocial mentoring support and career resilience," Eur. J. Psychol., vol. 11, no. 1, p. 16, 2015.

[30] D. Goleman, "Emotional Intelligence Bloomsbury," London, New Delhi, New York, sydney, 1996.

[31] J. J. Gross, Handbook of emotion regulation. Guilford publications, 2013.

[32] P. Muzumdar, "Influence of interactional justice on the turnover behavioral decision in an organization," J. Behav. Stud. Bus., vol. 5, pp. 31-41, 2012.

[33] J. R. Schermerhorn Jr, J. G. Hunt, and R. N. Osborn, Managing organizational behavior. Wiley, 1991.

[34] R. B. Cialdini and K. Ascani, "Test of a concession procedure for inducing verbal, behavioral, and further compliance with a request to give blood.," J. Appl. Psychol., vol. 61, no. 3, p. 295, 1976. 